\title{
PENGARUH STRATEGI PEMBELAJARAN DAN KOMPETENSI PEDAGOGIK GURU TERHADAP HASIL BELAJAR PADA MATERI SHALAT DI KELAS II (DUA) SDN RAMA 1 KOTA TANGERANG
}

\author{
Dian Astutik*, E.Kurniyati** \\ *dianastutik2@gmail.com,**etykurniyati@umt.ac.id \\ *Magister PAI Program Pascasarjana, Universitas Muhammadiyah Tangerang
}

\begin{abstract}
This study aims to find out the number of the influence of the learning strategy (X1), and pedagogical competence (X2) variables on the learning outcome variable (Y) of the prayer material at SDN Rama 1 Tangerang city, both partially and simultaneously. The method used in this study is a quantitative method, with respondents are all active students of Class II (two) of SDN Rama 1 in Tangerang City in the academic year of 2019/2020, which numbered 99 persons. The technique of analysis used are simple and multiple linear regression analysis, with the hypothesis test method are $t$ test and $f$ test. The results of the hypothesis tests state that partially or simultaneously the learning strategy (X1), and pedagogical competence (X2) variables have the positive and significant effects on the learning outcomes variable $(Y)$, with the number of influence of each one partially that is $32.4 \%$, and $76.4 \%$. However, the number of the simultaneous influence of the two independent variables on learning outcomes is $46.4 \%$, while the remaining $54.6 \%$ is influenced by other factors not examined in this study. Thus, if the learning strategy and teacher's pedagogical competence increase, the learning outcomes of the prayer material will also increase.
\end{abstract}

Keywords: learning strategy, pedagogical competence, and learning outcomes.

Tadarus Tarbawy. Vol. 3 No. 2 Jul - Des 2021. ISSN. 2657-1285 e-ISSN. 2656-8756 


\section{A. PENDAHULUAN}

Untuk mewujudkan penerapan prinsip-prinsip Islam dalam pembelajaran Pendidikan Agama Islam di sekolah, diperlukan adanya strategi pembelajaran. Strategi pembelajaran dapat diartikan sebagai "suatu pendekatan dalam mengorganisasikan komponen-komponen pembelajaran yang dibutuhkan untuk mencapai tujuan pembelajaran. (Hidayat, 2019:32)

Hal penting lainnya yang harus dimiliki oleh seorang guru adalah kompetensi sesuai bidangnya. Dalam Undang-Undang Republik Indonesia nomor 14 tahun 2005 tentang guru dan dosen bab I ketentuan umum pasal 1 poin 10 , dinyatakan bahwa: "kompetensi adalah seperangkat pengetahuan, keterampilan, dan perilaku yang harus dimiliki, dihayati, dan dikuasai oleh guru atau dosen dalam melaksanakan tugas keprofesionalan. (UU No 14, 2005)

Kompetensi yang sangat penting dimiliki oleh seorang guru adalah kompetensi pedagogik. Pengertian kompetensi pedagogik dalam Peraturan Pemerintah Republik Indonesia nomor 74 tahun 2008 tentang guru bab II kompetensi dan sertifikasi pasal 2 dan bagian kesatu kompetensi pasal 3 ayat (4). Kompetensi pedagogik adalah: kemampuan seseorang pendidik dalam mengelola pembelajaran peserta didik yang meliputi: a) Pemahaman wawasan atau landasan pendidikan, $b$ ) Pemahaman terhadap peserta didik, $c$ ) Pengembangan kurikulum atau silabus, $d$ ) Perancangan pembelajaran, e) Pelaksanaan pembelajaran yang mendidik dan dialogis, f) Pemanfaatan teknologi pembelajaran, $g$ ) Evaluasi hasil belajar, $h$ ) Pengembangan peserta didik untuk mengaktualisasikan berbagai potensi yang dimiliki. (PP No74, 2008)

Studi-studi menunjukkan bahwa peserta didik lebih banyak belajar jika pelajarannya memuaskan, menantang, dan ramah serta mereka mempunyai suara dalam

pembuatan

keputusan

(Walberg,1997). (Deporter, 2000:54)

Dengan demikian, keberhasilan guru dalam pembelajaran dapat dilihat dari sudut pandang peserta didiknya, dikatakan berhasil apabila selama proses pembelajaran peserta didik merasa senang dan memberi feedback positif terhadapnya, bukan penilaian formal dari rekan-rekannya sesama guru. (Huda, 2013:13)

Penelitian ini secara khusus akan dilaksanakan di SDN Rama 1 kota Tangerang. Adapun alasan sekolah ini dijadikan sebagai tempat penelitian karena berdasarkan hasil wawancara yang penulis lakukan dengan guru Pendidikan Agama Islam yang ada di sekolah tersebut, menunjukkan bahwa hasil belajar pada materi praktik shalat di kelas dua masih sangat rendah. Rendahnya hasil belajar peserta didik ini terlihat dari 99 peserta didik, yang mampu menguasai tata cara shalat yang benar sesuai dengan bacaan dan gerakannya hanya sekitar $50 \%$ dengan kriteria ketuntasan belajar minimal sebesar 75,00 . Penulis menganggap permasalahan ini sangat penting, karena ibadah shalat merupakan tolak ukur pertama seorang muslim dalam berkomitmen terhadap ajaran agama Islam. Berfungsi sebagai peletakkan dasar-dasar keilmuan, maka pendidikan sekolah dasar merupakan waktu yang tepat untuk mengajarkan pembiasaan ibadah shalat sebagai bentuk amalan ibadah harian sehingga diperlukan bimbingan dengan baik dan benar. Dari pemaparan latar belakang di atas, maka penelitian ini penulis beri judul 'Pengaruh Strategi Pembelajaran dan Kompetensi Pedagogik Guru terhadap Hasil Belajar pada materi shalat di kelas II (dua) SDN Rama 1 kota Tangerang"

\section{B. METODE PENELITIAN}

Jenis penelitian yang digunakan dalam penelitian ini adalah penelitian kuantitatif dengan pendekatan deskriptif. Menurut Sugiyono, metode penelitian kuantitatif dapat diartikan sebagai metode 
penelitian yang berlandaskan pada filsafat positivism, digunakan untuk meneliti pada populasi atau sampel tertentu, teknik pengambilan sampel pada umumnya dilakukan secara random, pengumpulan data menggunakan instrumen penelitian, analisis data bersifat kuantitatif/statistik tujuan untuk menguji hipotesis yang telah ditetapkan. (Sugiyono, 2012: 8)

Sedangkan pengertian deskriptif adalah metode yang berfungsi untuk mendeskripsikan atau memberi gambaran terhadap objek yang diteliti melalui data sampel yang telah terkumpul sebagaimana adanya, tanpa melakukan analisis dan membuat kesimpulan yang berlaku umum. (Sugiyono, 2012: 29)

Populasi dalam penelitian ini adalah semua kelas II (dua) SDN Rama 1 kota Tangerang, yang terdiri dari tiga rombel kelas dengan jumlah 41 laki-laki dan 58 perempuan.

Teknik dan alat pengumpulan data yang digunakan dalam penelitian ini adalah berupa tes, angket, wawancara, observasi dan dokumentasi.

Sebelum instrumen penelitian berupa kuesioner disebarluaskan sebaiknya perlu diadakan uji kelayakan terlebih dahulu. Menurut Suharsimi Arikunto, instrumen pengumpulan data adalah alat bantu yang dipilih dan digunakan oleh peneliti dalam kegiatannya mengumpulkan data agar kegiatan tersebut menjadi sistematis dan dipermudah olehnya. (Arikunto, 2010: 265) Teknik analisis data dalam penelitian ini terdiri dari; Uji Validitas Instrumen, Uji Reliabilitas Instrumen, Uji Normalitas Residual, Uji Multikolinearitas, dan Uji Heteroskedastisitas.

\section{HASIL DAN PEMBAHASAN}

\section{Pengujian Persyaratan Analisis.}

\section{Hasil Uji Normalitas Residual.}

Uji normalitas residual dihitung menggunakan rumus Kolmogorov Smirnov SPSS 26, dengan hasil sebagai berikut:
Tabel 4.11

OUTPUT UJI NORMALITAS KOLMOGOROV - SMIRNOVa

\begin{tabular}{|l|l|r|}
\hline \multicolumn{2}{|c|}{ One-Sample Kolmogorov-Smirnov Test } \\
\hline & & \multicolumn{1}{c|}{$\begin{array}{c}\text { Unstandardized } \\
\text { Residual }\end{array}$} \\
\hline N & & 09 \\
\hline $\begin{array}{l}\text { Normal } \\
\text { Parameters ab }\end{array}$ & Mean & 0.89906779 \\
\hline & Std. Deviation & 0.072 \\
\hline $\begin{array}{l}\text { Most } \\
\text { Extreme } \\
\text { Differences }\end{array}$ & Absolute & 0.065 \\
\hline & Positive & -0.072 \\
\hline & Negative & 0.072 \\
\hline Test Statistic & & $.200^{c .0}$ \\
\hline $\begin{array}{l}\text { Asymp. Sig. } \\
\text { (2-tailed) }\end{array}$ & & \\
\hline
\end{tabular}

a. Test distribution is Normal

b. Calculated from data.

c. Lilliefors Significance Correction.

d. This is a lower bound of the true significance. lebih besar dari nilai alpha $(0,05)$ atau ditulis sig. $(0,200)>\propto(0,05)$, maka artinya bahwa semua variabel berdistribusi normal.

\section{Hasil Uji Multikolinieritas.}

Uji multikolinieritas dengan melihat nilai Tolerance dan VIF (Variance Inflation Factor) melalui SPSS 26, dengan hasil sebagai berikut :

Tabel 4.12

\section{OUTPUT UJI MULTIKOLINIERITAS SPSS 26}

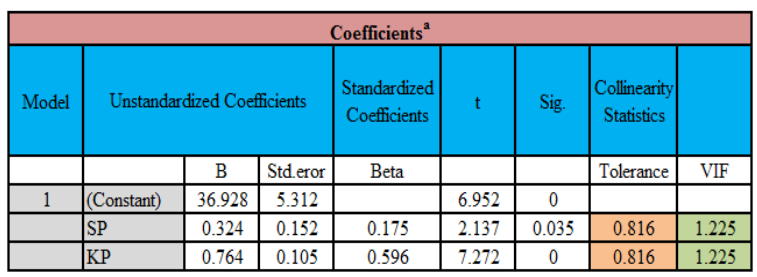

Sumber data: SPSS 26 
Dari tabel di atas dapat diketahui nilai Tolerance lebih dari 0,10 dan nilai VIF kurang dari 10 , artinya tidak terjadi gejala Multikolinieritas.

\section{Hasil Uji Heteroskedastisitas.}

Uji heteroskedastisitas ini dilakukan menggunakan SPSS 26, dengan hasil sebagai berikut :

Gambar 4.4

CHARTS UJI

HETEROSKEDASTISITAS

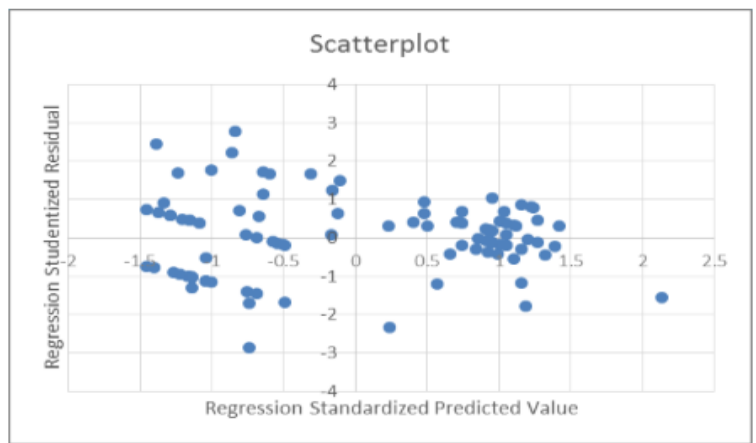

Sumber : SPSS 26

Dari gambar titik-titik data penyebar di atas dapat diketahui bahwa data menyebar disekitar angka nol, data tidak mengumpul pada satu bagian saja, data tidak membentuk pola bergelombang, maka artinya bahwa data tersebut menunjukkan tidak terjadi gejala Heteroskedastisitas sehingga data pada penelitian ini tidak diragukan keakuratannya.

\section{Hasil Pengujian Hipotesis.}

Untuk mengetahui ada tidaknya pengaruh strategi pembelajaran dan kompetensi pedagogik terhadap hasil belajar pada materi shalat, baik secara parsial (individu) maupun secara simultan (bersama) maka perlu dilakukan uji t dan uji $\mathrm{F}$ dalam analisis regresi berganda melalui SPSS 26, dengan hasil sebagai berikut :

Tabel 4.13

\section{OUTPUT UJI t}

\begin{tabular}{|c|c|c|c|c|c|c|}
\hline \multicolumn{7}{|c|}{ Coefficients $^{2}$} \\
\hline \multirow[t]{2}{*}{ Model } & \multicolumn{3}{|c|}{ Unstandardized Coefficients } & \multirow{2}{*}{\begin{tabular}{|c|}
$\begin{array}{c}\text { Standardized } \\
\text { Coefficients }\end{array}$ \\
Beta \\
\end{tabular}} & \multirow[t]{2}{*}{$\mathrm{t}$} & \multirow[t]{2}{*}{ Sig. } \\
\hline & & $\mathrm{B}$ & Stderor & & & \\
\hline \multirow[t]{3}{*}{1} & (Constant) & 36.928 & 5.312 & & 6.952 & 0 \\
\hline & SP & 0.324 & 0.152 & 0.175 & 2.137 & 0.035 \\
\hline & $\mathrm{KP}$ & 0.764 & 0.105 & 0.596 & 7.272 & 0 \\
\hline
\end{tabular}

\section{Hasil Pengujian Hipotesis 1.}

Dari tabel uji $t$ di atas dapat diketahui nilai signifikansi untuk strategi pembelajaran terhadap hasil belajar sebesar sig. $(0,035)<\propto(0,05)$ dan nilai t hitung $(2,137)>\mathrm{t}$ tabel $(1,98498)$, artinya terdapat pengaruh antara strategi pembelajaran terhadap hasil belajar pada materi praktik shalat. Jadi keputusannya H0 ditolak, H1 diterima.

\section{Hasil Pengujian Hipotesis 2.}

Dari tabel uji t di atas dapat diketahui nilai signifikansi untuk kompetensi pedagogik terhadap hasil belajar sebesar sig. $(0,000)<\propto(0,05)$ dan nilai t hitung $(7,272)>t$ tabel $(1,98498)$, artinya terdapat pengaruh antara kompetensi pedagogik terhadap hasil belajar pada materi praktik shalat. Jadi keputusannya H0 ditolak, H1 diterima.

\section{Hasil Pengujian Hipotesis 3.}

Untuk membuktikan adanya pengaruh strategi pembelajaran dan kompetensi pedagogik secara simultan (bersama) terhadap hasil belajar pada materi praktik shalat, maka dilakukan uji F. Hasil dari uji $F$ yang dilakukan dengan menggunakan SPSS 26 adalah sebagai berikut :

Tabel 4.14

OUTPUT UJI F

\begin{tabular}{|c|c|c|c|c|c|c|}
\hline \multicolumn{7}{|c|}{ ANOVA $^{\mathbf{a}}$} \\
\hline Model & & $\begin{array}{l}\text { Sum of } \\
\text { Squares }\end{array}$ & df & $\begin{array}{l}\text { Mean } \\
\text { Square }\end{array}$ & F & Sig. \\
\hline 1 & Regressio & 4214.03 & 2 & 2107.01 & 43.364 & $.000^{\mathrm{b}}$ \\
\hline & nesidual & 4664.52 & 96 & 48.589 & & \\
\hline & Total & 8878.55 & 98 & & & \\
\hline $\begin{array}{l}\text { a. Dependent Variable: HB } \\
\text { b. Predictors: (Constant), KP, SP }\end{array}$ \\
\hline
\end{tabular}


Dari tabel uji F di atas dapat diketahui nilai signifikansi sig. $(0,000)<\propto(0,05)$ atau nilai $\mathrm{F}$ hitung $(43,364)>\mathrm{F}$ tabel $(3,09)$ maka artinya terdapat pengaruh antara strategi pembelajaran dan kompetensi pedagogik secara simultan (bersama) terhadap hasil belajar pada materi praktik shalat.

\section{Koefisien Determinasi}

Untuk mengetahui berapa besar pengaruh antara strategi pembelajaran dan kompetensi pedagogik terhadap hasil belajar pada materi praktik shalat maka dilakukan uji $\mathrm{R}$ Square (Koefisien Determinasi) menggunakan SPSS 26, dengan hasil sebagai berikut :

Tabel 4.15

\section{OUTPUT UJI KOEFISIEN} DETERMINASI (R SQUARE)

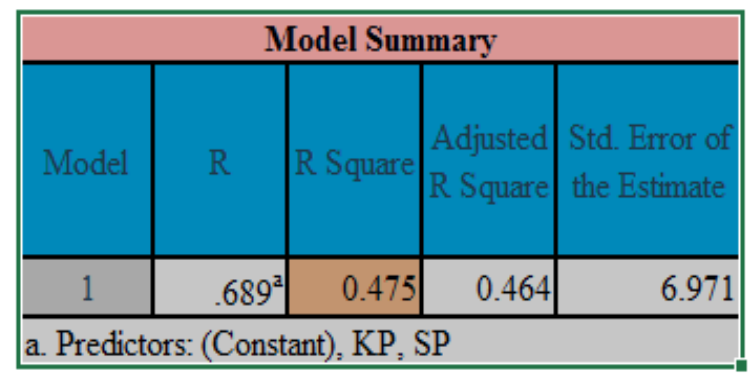

Dari uji R Square di atas didapatkan nilai Adjust $\mathrm{R}$ Square (Koefisien Determinasi) sebesar 0,475 yang artinya pengaruh strategi pembelajaran dan kompetensi pendidikan terhadap hasil belajar pada materi praktik shalat sebesar 0,475 atau $47,5 \%$ dengan interpretasi pengaruhnya sedang.

\section{Berganda}

Persamaan Regresi Linier

Persamaan model regresi linier berganda secara matematis ditulis sebagai berikut:

$$
\mathrm{Y}=\mathrm{a}+\mathrm{b}_{1} \mathrm{X}_{1}+\mathrm{b}_{2} \mathrm{X}_{2}+\mathrm{e}
$$

Keterangan:

$\mathrm{Y}=$ Hasil belajar pada materi shalat

a $\quad=$ Konstanta

$\mathrm{X}_{1}=$ Strategi pembelajaran

$\mathrm{X}_{2} \quad=$ Kompetensi pedagogik

$\mathrm{b}_{1} \mathrm{~b}_{2}=$ Koefisien regresi

e $\quad=$ error

Dengan melihat uji t pada tabel 4.14 didapat nilai konstanta sebesar 36,928, koefisien regresi strategi pembelajaran $(0,324)$ dan koefisien regresi kompetensi pedagogik $(0,764)$. Sehingga persamaan regresinya dapat ditulis :

$$
\mathrm{Y}=36,928+0,324 \mathrm{X} 1+0,764 \mathrm{X} 2
$$

Interpretasi dari persamaan regresi tersebut adalah, jika X1 dan X2 bernilai nol, maka hasil belajar bernilai 36,928. Dalam arti lain bahwa tanpa strategi pembelajaran dan kompetensi pedagogik hasil belajar peserta didik bernilai 36,928 .

\begin{tabular}{lcr}
\multicolumn{1}{c}{ Koefisien } & regresi & strategi \\
pembelajaran & sebesar & 0,324, \\
$\mathrm{Y}=36,928+0,324 \mathrm{X} 1$ & artinya & setiap
\end{tabular}
peningkatan strategi pembelajaran akan memberikan peningkatan kearah positif kepada hasil belajar peserta didik sebesar 0,8324 atau $32,4 \%$.

Koefisien regresi $r$ kompetensi
pedagogik sebesar $r$ artinya setiap
$\mathrm{Y}=36,928+0,764 \mathrm{X} 2$,
peningkatan kompetensi pedagogik akan
memberikan peningkatan kearah positif
kepada hasil belajar peserta didik sebesar
0,764 atau $76,4 \%$.

\section{Pembahasan}

Dari beberapa uji penelitian yang telah dilakukan, terdapat tiga pembahasan yang menjadi rumusan pada penelitian ini, antara lain :

a. Hasil pengujian pengaruh strategi pembelajaran terhadap hasil belajar pada materi shalat. 
Dari uji $\mathrm{t}$ pada tabel 4.13 diketahui $\mathrm{t}$ hitung lebih besar dari t tabel sehingga dapat diambil keputusan bahwa $\mathrm{H} 0$ yang berbunyi tidak ada pengaruh antara strategi pembelajaran terhadap hasil belajar pada materi shalat ditolak dan $\mathrm{H} 1$ yang berbunyi terdapat pengaruh antara strategi pembelajaran dan hasil belajar pada materi shalat diterima.

b. Hasil pengujian pengaruh kompetensi pedagogik terhadap hasil belajar pada materi shalat.

Dari uji t pada tabel 4.13 diketahui $\mathrm{t}$ hitung lebih besar dari t tabel sehingga diambil keputusan bahwa $\mathrm{H} 0$ yang berbunyi tidak ada pengaruh antara kompetensi pedagogik terhadap hasil belajar pada materi shalat ditolak dan H1 yang berbunyi terdapat pengaruh antara kompetensi pedagogik terhadap hasil belajar pada materi shalat diterima.

c. Hasil pengujian pengaruh strategi pembelajaran dan kompetensi pedagogik secara simultan terhadap hasil belajar pada materi shalat.

Dari uji $\mathrm{F}$ pada tabel 4.14 diketahui $\mathrm{F}$ hitung lebih besar dari $\mathrm{F}$ tabel sehingga diambil keputusan bahwa $\mathrm{HO}$ yang berbunyi tidak ada pengaruh antara strategi pembelajaran dan kompetensi pedagogik secara simultan (bersama) terhadap hasil belajar pada materi shalat ditolak dan $\mathrm{H} 1$ yang berbunyi terdapat pengaruh antara strategi pembelajaran dan kompetensi pedagogik secara simultan (bersama) terhadap hasil belajar pada materi shalat diterima.

\section{KESIMPULAN}

Dari hasil analisis penelitian pengaruh strategi pembelajaran dan kompetensi pedagogik terhadap hasil belajar pada materi praktik shalat di kelas II (dua) SDN Rama 1 kota Tangerang, dapat dikemukakan beberapa kesimpulan antara lain :

Secara parsial (individu), strategi pembelajaran memiliki pengaruh yang signifikan kearah positif terhadap hasil belajar pada materi shalat. Hal ini dapat dibuktikan pada uji $\mathrm{t}$, dimana $\mathrm{t}$ hitung $(2,137)>t$ tabel $(1,98498)$. Besaran pengaruhnya yaitu sebesar 0,324 atau $32,4 \%$, artinya setiap kenaikan strategi pembelajaran dapat meningkatkan hasil belajar sebesar 0,324 atau $32,4 \%$ dengan interpretasi pengaruhnya berkategori lemah/rendah.

Secara parsial (individu), kompetensi pedagogik memiliki pengaruh yang signifikan kearah positif terhadap hasil belajar pada materi shalat. Hal ini dapat dibuktikan pada uji $\mathrm{t}$, dimana $\mathrm{t}$ hitung $(7,272)>t$ tabel $(1,98498)$. Besaran pengaruhnya yaitu sebesar 0,764 atau $76,4 \%$, artinya setiap kenaikan strategi pembelajaran dapat meningkatkan hasil belajar sebesar 0,764 atau $76,4 \%$ dengan interpretasi pengaruhnya berkategori kuat/tinggi.

Secara simultan (bersama), strategi pembelajaran dan kompetensi pedagogik memiliki pengaruh yang signifikan kearah positif terhadap hasil belajar pada materi shalat. Hal ini dapat dibuktikan pada uji F, dimana F hitung $(43,364)>F$ tabel $(3,09)$. Besaran pengaruhnya yaitu sebesar 0,475 atau $47,5 \%$, artinya setiap kenaikan strategi pembelajaran dan kompetensi pedagogik secara simultan (bersama) dapat meningkatkan hasil belajar sebesar 0,475 atau $47,5 \%$ dengan interpretasi pengaruhnya berkategori sedang. Sedangkan $52,5 \%$ dipengaruhi oleh faktor lain yang tidak diteliti pada penelitian ini.

\section{DAFTAR PUSTAKA}

Arikunto, Suharsimi, 2010, Prosedur Penelitian suatu Pendekatan Praktik, Yogyakarta: Rineka Cipta. 
Deporter, Bobbi, 2000, Quantum Teaching, Edisi.1, Cet.1, Bandung: Mizan Pustaka.

Hasil Olah Data Tanggal 16 Juli 2020 Menggunakan SPSS versi 26

Hidayat, Isnu, 2019, 50 Strategi Populer, Cet.1, Yogyakarta: Diva Press.

Huda, Miftahul, 2013, Model-model Pengajaran dan Pembelajaran, Cet.1, Yogyakarta: Pustaka Pelajar.

Peraturan Pemerintah No 74, 2008, tentang Guru.

Priyatno, Duwi, 2018, SPSS Panduan Mudah Olah Data bagi Mahasiswa \& Umum, Ed.1, Yogyakarta: Andi Offset.

Sugiyono, 2012, Metode Penelitian Kuantitatif Kualitatif Dan $R \& D$, Bandung: Alfabeta.

Undang-Undang No. 14, 2005, tentang Guru dan Dosen. 